\title{
Isolation of Thermophilic Bacteria and Optimizing the Medium Growth Conditions
}

\author{
Gustina Indriati and Ruth Rize Paas Megahati* \\ Biology Educational Department STKIP PGRI Sumbar, Padang, West Sumatera, Indonesia \\ *Corresponding author
}

\begin{abstract}
A B S T R A C T
The thermophile bacteria that came from hot spring, generally, it is thermostable, which it

Keywords

Isolation,

Thermophile

bacteria, Amylase,

Optimization,

Growth medium

Article Info

Accepted:

12 December 2017

Available Online:

10 January 2018

can produce enzyme. For example, there are protease, lipase, and amylase. Amylase produced by bacteria or bacteria amylase is an enzyme that can hydrolyze starch to sugar. The thermostable of amylase resist to high temperature and $\mathrm{pH}$. It has been used on many industrial productions like foods, fermentation, textile, alcohol, paper, pharmaceutical and detergent. Screening of thermo-amylase bacteria in a hot spring needs to be done because the hot springs got potential as a source of thermostable amylase producing bacteria. Thermostable amylase that produced by natural bacteria (wild type) usually has activity that is not too high. The aim of this study is to get thermophile bacteria that produced thermostable amylase and increased the activity of thermostable amylase through optimization the condition of growth medium of thermophile bacteria. The result of this study is found 16 thermophile isolate bacteria and 3 thermophile bacteria that produced amylase. Thermostable amylase activity was high by using the agitation $125 \mathrm{rpm}$, wheat flour as the substrate at a concentration of $2 \%$ and amylase stability for 2 hours at 40 $50^{\circ} \mathrm{C}$. Thermostable amylase produced SMG9 of bacterial isolates that can be used in various industries.
\end{abstract}

\section{Introduction}

Thermophile bacteria lives at $45^{\circ} \mathrm{C}-80^{\circ} \mathrm{C}$ and produce enzyme which are thermostable. Enzyme that came from thermophile bacteria also known as thermophile enzyme because of thermostable and thermo-active (Fooladi and Sajjadian, 2012). The thermophile enzyme, like protease, lipase and amylase that are thermostable happened because those werere sistant to high temperature and $\mathrm{pH}$. Thermostable amylase had been used in so many industrial areas, foods, fermentations, textiles, alcohols, papers, pharmaceuticals and detergents (Mageswari et al., 2012). Amylase produced by bacteria or bacteria amylase is an enzyme that can hydrolyze starch to sugar (Megahati et al., 2017). Thermostable amylase that had been used in industry was 30\% from all enzymes around the world (Munoz et al., 2011).

Today, the number of bacteria that can produce thermostable amylase is still limited and the screening for this is still less information especially when its sources came 
from a hot spring. Indonesia has so many sources of hot spring likes, Rimbo Panti hot spring, Ciater hot spring, Sibiru-biru hot spring and Semurup hot spring. Semurup hot spring was located in Kerinci District, Jambi Province, Indonesia. It had $75^{\circ} \mathrm{C}$ temperature and $\mathrm{pH}$ 8.4. All this time, hot spring of Semurup had not been used yet as source of bacteria producing thermostable amylase.

Thermostable amylase that was produced by nature bacteria (wild-type), like on a hot spring, usually have no high activity. Because of it, it needs isolation of thermophile bacteria that can produce thermostable amylase and optimization of growth medium thermophile bacteria. This study has aim to get thermophile bacteria that produced thermostable amylase and increased thermostable amylase activity through optimization growth medium conditions of thermophile bacteria likes the different of agitation speed, carbon sources, source carbon concentration, and amylase stability test.

\section{Materials and Methods}

\section{The sample collection and medium}

Isolate of bacteria SMG9 was earned at temperature $75^{\circ} \mathrm{C}$ from Semurup hot spring, Kerinci District, Jambi Province, Indonesia. Medium growth used in this study is Nutrient agar $(20 \mathrm{~g} / \mathrm{l})$, substrate agar 1\%, and medium of production. All mediums were sterilized by autoclave at $121^{\circ} \mathrm{C}$ for 15 minutes.

\section{Isolation and screening of bacteria}

Hot spring sample $250 \mathrm{ml}$ is get into the bottle sample and then labeled. Next, it brings into laboratory and then $1 \mathrm{ml}$ of sample spread into Nutrient agar $(20 \mathrm{~g} / \mathrm{l})$ medium. After that, it is incubated at temperature $50^{\circ} \mathrm{C}$ for 24 hours. Thermophile bacteria is growing planted into medium of selective starch agar 1\% (10 g/l starch and $15 \mathrm{~g} / \mathrm{l}$ bacto agar) and incubated at temperature $50^{\circ} \mathrm{C}$ for 24 hours. Bacteria that was grown on selective medium was dripped with iodine solution. Amylase activity is showed with the creation of clear zone on the selective medium. Bacteria with the widest clear zone was used to the further research.

\section{Enzyme isolation}

The thermophile bacteria isolation that has had the widest clear zone then planted into $50 \mathrm{ml}$ medium of production $\left(0.75 \mathrm{~g} \mathrm{KH}_{2} \mathrm{PO}_{4}, 0.75 \mathrm{~g}\right.$ $\mathrm{K}_{2} \mathrm{HPO}_{4}, 1.25 \mathrm{~g} \mathrm{MgSO}_{4}, 1.25 \mathrm{~g} \mathrm{NaCl}, 2.5 \mathrm{~g}$ starch) with $\mathrm{pH} 8.5$ and shaked with $150 \mathrm{rpm}$ for 24 hours at temperature $50^{\circ} \mathrm{C}$. Next, the culture as much $10 \%$ moved into $100 \mathrm{ml}$ new medium of production with $\mathrm{pH} 8.5$ and shaker (150 rpm) for 24 hours at temperature $60^{\circ} \mathrm{C}$. The bacterial that growth inside the culturing and then centrifuged with 10.000 speed for five minutes. The supernatant moved into new micro-centrifuged tube for amylase test (Teodoro and Martin, 2010).

\section{Amylase testing}

The $0.5 \mathrm{ml}$ substrate $1 \%$ blended with Pottasium phosphate buffer with $\mathrm{pH} 7.0$ is incubated at temperature $50^{\circ} \mathrm{C}$ for 5 minutes and added with $0.5 \mathrm{ml}$ thermostable amylase. Then, it is incubated at temperature $50^{\circ} \mathrm{C}$ for one hour. Enzyme activity was stopped by making heat on substrate-thermostable amylase with boiling the water for 20 minutes.

Then, adding $1 \mathrm{ml}$ Samogyi-Nelson solution (Nelson, 1944). The solution was cooled down on ice for one minute, then adding $1 \mathrm{ml}$ Arsenomolibdat solution. Next, it was blended with vortex machine and measured its absorbance on wave length $540 \mathrm{~nm}$. One unite enzyme was definite as numbers of enzyme that release one $\mu \mathrm{mol}$ sugar per minute from the substrate for 60 minutes at temperature $50^{\circ} \mathrm{C}$. 


\section{The effect of different speed agitation}

The medium of production that had been inoculated with thermophile bacteria was shacked with different speed of agitation (100$200 \mathrm{rpm}$ ) at temperature $60^{\circ} \mathrm{C}$ for 24 hours. $10 \%$ inoculum moved into new $100 \mathrm{ml}$ medium of production and then it was shacked with other different speed of agitation (100$200 \mathrm{rpm}$ ) for 24 hours. Culturing bacteria was centrifuged with speed $10.000 \mathrm{rpm}$ for five minutes. The supernatant, produce during this process, was moved into new micro-centrifuge tube for amylase test.

\section{The effect of different carbon source}

So many source of carbon were added into production medium thermophile bacteria likes potatoes flour, rice flour, sago flour, wheat flour, and corns flour each with $1 \%$ concentration. Medium was shake with speed $100 \mathrm{rpm}$ (optimized result) on temperature $60^{\circ} \mathrm{C}$ for 24 hours. $10 \%$ of culturing was moved into new medium production and then it was shacked with agitation speed $100 \mathrm{rpm}$ for 24 hours. The culturing bacterial was centrifuged with speed $10.000 \mathrm{rpm}$ for 5 minutes. The supernatant that produced during it was isolated and moved into new microcentrifuged tube for amylase test.

\section{The effect of different carbon source concentration}

Isolate of thermophile bacteria was planted into $50 \mathrm{ml}$ medium production with $\mathrm{pH} 8.5$ and using wheat flour as a carbon source (optimization result). Different concentration of wheat flour was used (1-5\%) and shacked with speed $100 \mathrm{rpm}$ at temperature $60^{\circ} \mathrm{C}$ for 24 hours. Culturing bacteria around $10 \%$ was moved into $100 \mathrm{ml}$ new medium production and shacked with speed $100 \mathrm{rpm}$ for 24 hours. Culturing bacteria was centrifuged with speed $10.000 \mathrm{rpm}$ for five minutes. The supernatant that contain extract of amylase was took with micropipette and got into micro-centrifuged tube for amylase test.

\section{Amylase stability test}

Amylase was got from optimization result condition of growth medium of thermophile bacteria then tested for its stability. Amylase stability was identified using incubation of amylase at temperature $40-90^{\circ} \mathrm{C}$ for two hours in the water bath.

\section{Results and Discussion}

\section{Isolation and screening bacteria}

Isolation of thermophile bacteria had been done at temperature $75^{\circ} \mathrm{C}$ on hot spring Semurup, Kerinci, Jambi province, Indonesia. The result was found 16 isolate of thermophile bacteria and 3 isolates of amylase producer (SMG9, SMG10, dan SMG11) with the creation of clear zone at around bacteria growth (Figure 1). The clear zone showed that starch was found inside medium has been hydrolyzed with amylase. Another study had also been succeeded to isolate the thermophile bacteria producer of amylase on hot spring in Myanmar and got 4 isolate bacteria producer of amylase (Win et al., 2015). Even though on the hot spring at Saudi Arabia, it was found 3 isolates degrading of starch (Khalil, 2011) and 6 isolates of hot spring Odishi, India (Kumar, 2014). Screening of thermophile bacteria that produce amylase needs to be done on the hot spring for exploring the natural resource and getting new bacteria that produce amylase.

\section{The effect of different agitation speed}

Agitation speed had affected on thermophile bacteria growth SMG9 and thermostable amylase production (Figure 2). Agitation speed around $125 \mathrm{rpm}$ can increase thermophile bacteria growing SMG9 and 
thermostable amylase production. Agitation speed at under or up to $125 \mathrm{rpm}$ can make decreasing thermostable amylase production. It is different with agitation speed on medium growth Bacillus licheniformis BT5.9 where the agitation speed $100 \mathrm{rpm}$ can increase growth of thermophile bacteria and amylase production (Ibrahim et al., 2013). The optimization production of amylase of Bacillus licheniformis AH214 was found with agitation speed $160 \mathrm{rpm}$ (Nabey and Farag, 2016). In the meantime, the Bacillus licheniformis ATCC6346 had produce amylase with agitation speed $100 \mathrm{rpm}$ (Vengadaramana et al., 2014). Agitation speed is benefit for good mixing through out the fermentation which ensuring sufficient oxygen transfer in aerobic culture, and consequenting improves the cell growth and metabolite synthesis. But too high agitation speed results in intensive shear forces, and in turn causes damage to cell structure and decrease in the yield of secondary metabolite (Gao \&WenYing 2007).

\section{The effect of different of carbon source}

Production and activity of amylase of thermophile bacteria SMG9 was increase using wheat flour as carbon source then the others (Figure 3). Biosynthesis of the enzyme was took place not only in the presence of starch but also with other carbon sources (Deb et al., 2013). Production and activity of amylase is increase using tapioca flour as carbon source on medium growth of Bacillus sp (Sreekanth et al., 2013). On the Bacillus tequilensis RG-01, amylase production was increased using wheat bran as carbon source (Tiwari et al., 2014). It is different on Bacillus subtilis BI19 where it was using of rice flour as carbon source can stimulate amylase production. Natural carbon source can be used by bacterial as energy source to produced amylase and it can be get with low price (Dash et al., 2015). The different of carbon sources have varied influence on the production of extracellular enzymes especially amylase (Rao and Sathyanarayana 2003).

Fig.1 The clear zone of isolate of thermophile bacteria

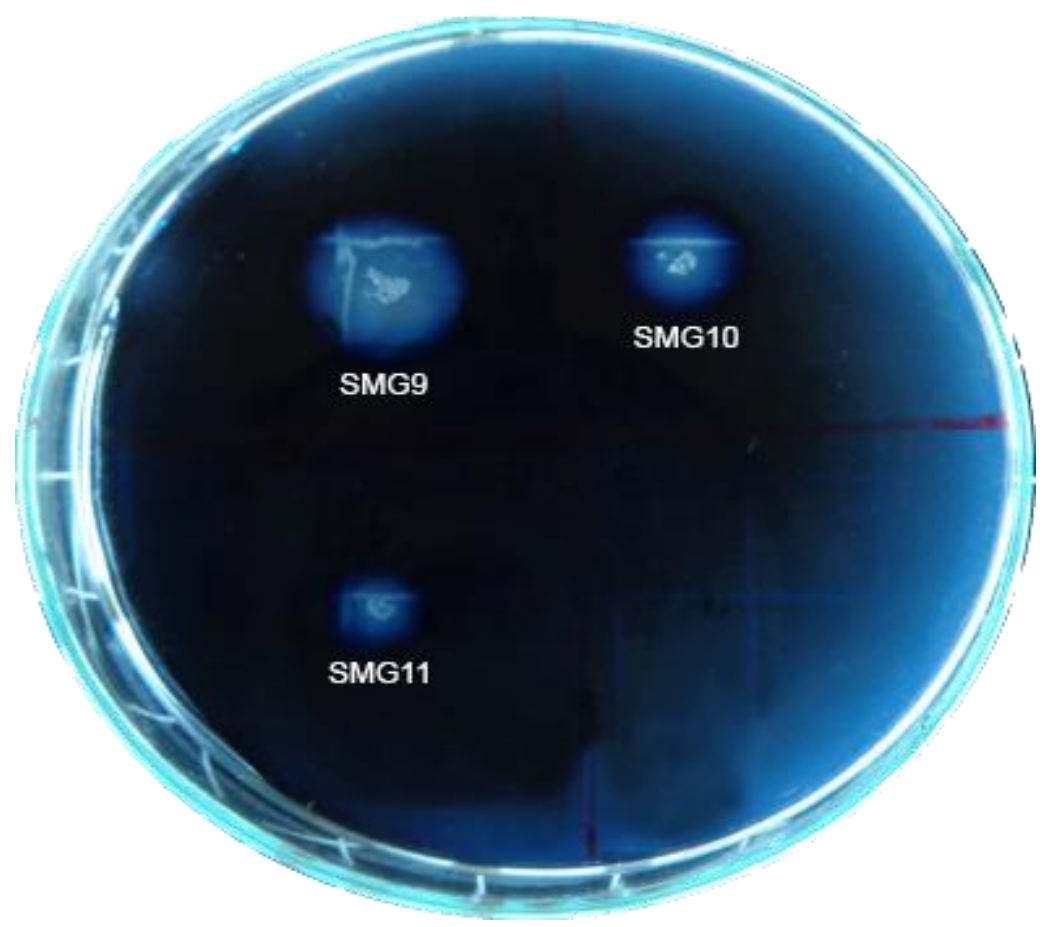


Fig. 2 The effect of different speed agitation on amylase production

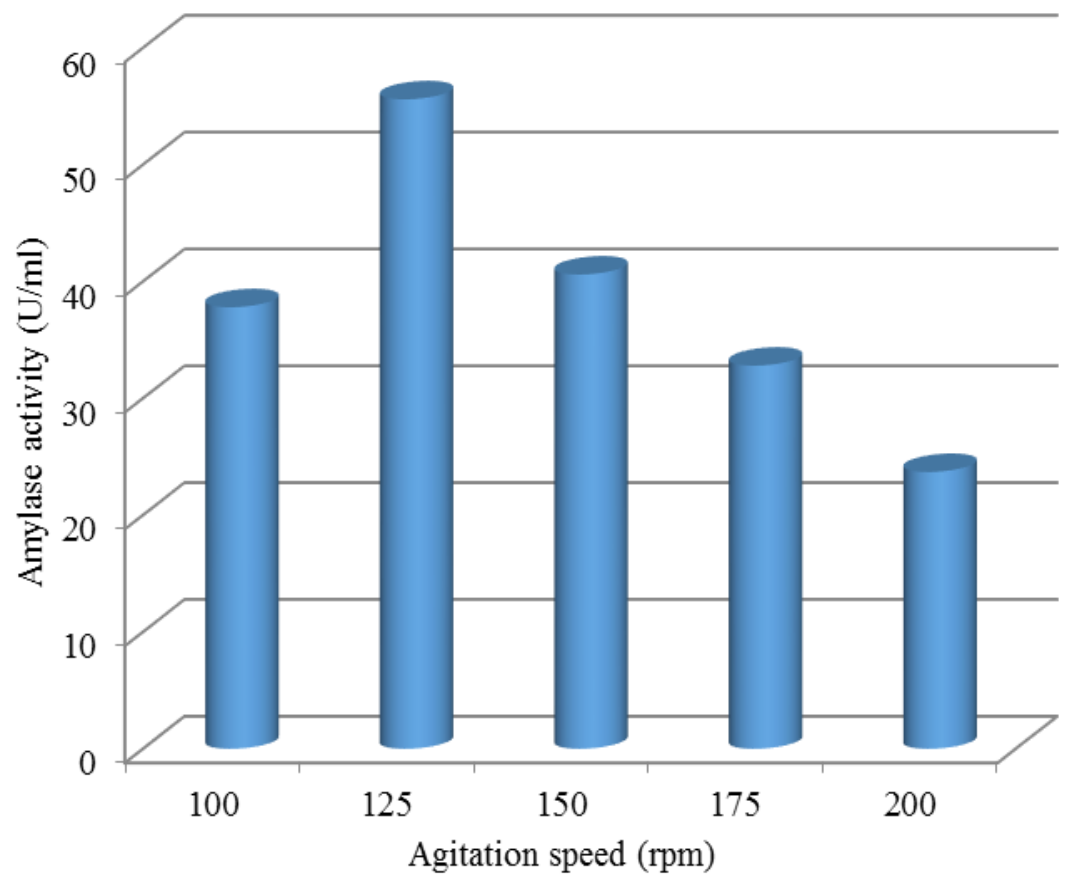

Fig.3 The effect of different carbon sources on amylase production

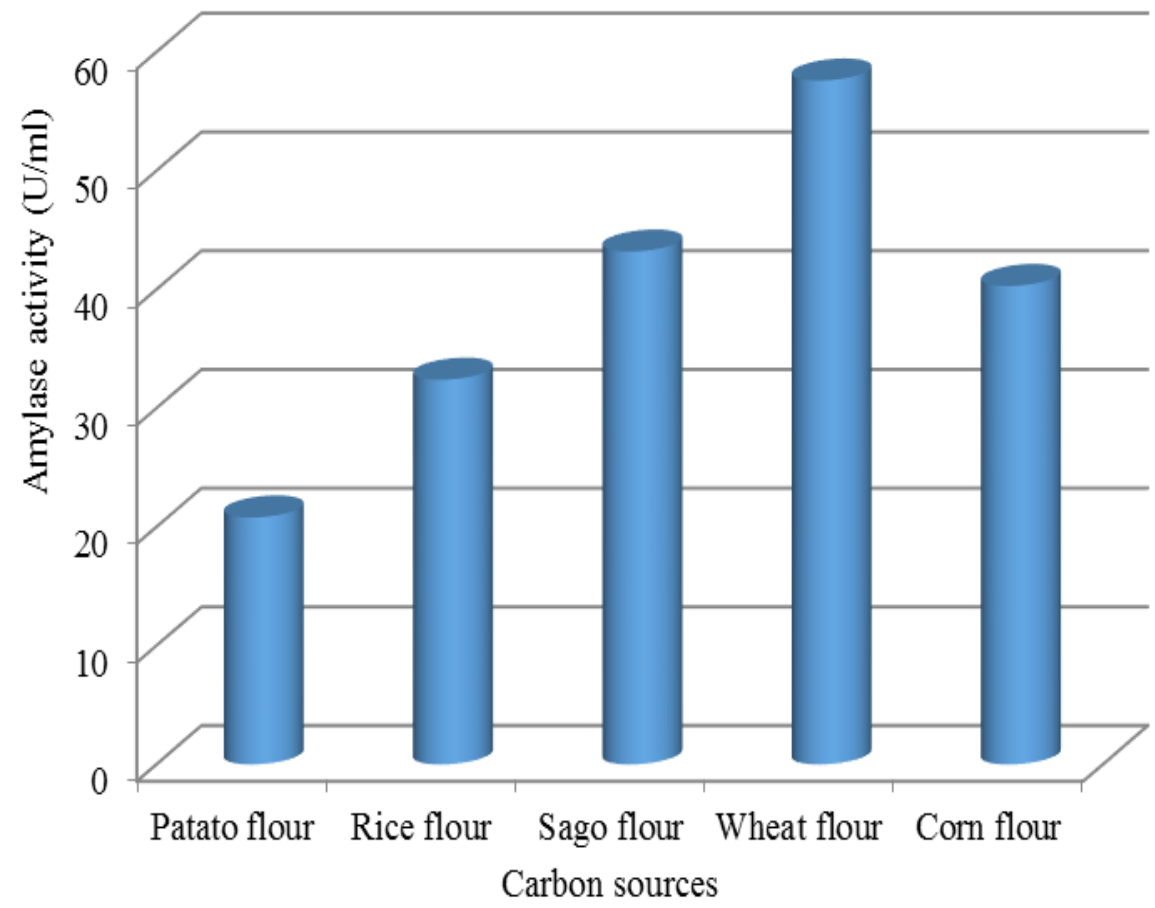


Fig.4 The effect of concentration variation of wheat flour

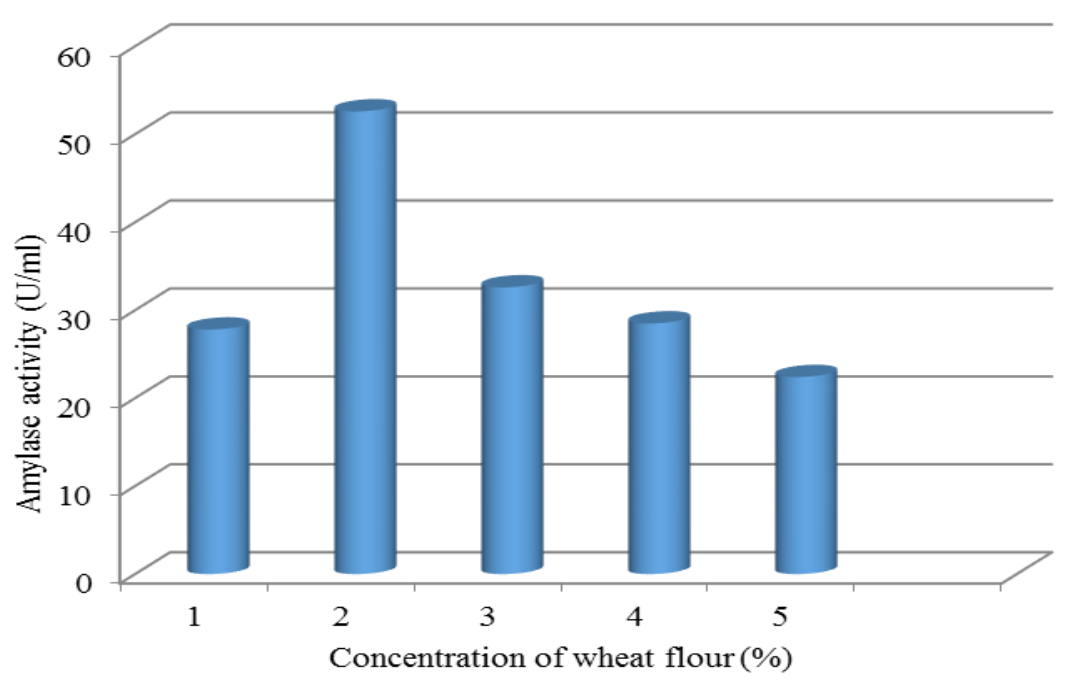

Fig.5 Amylase stability

120

100

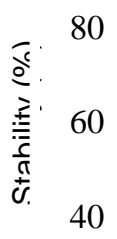

20

0

$\begin{array}{cccccc}40 & 50 & 60 & 70 & 80 & 90 \\ & & & \text { Temperature }\left({ }^{\circ} \mathrm{C}\right) & & \end{array}$

The effect of variation of carbon source concentration

Concentration of wheat flour is very effecting on amylase activity that produced by thermophile bacteria. High or low concentration of wheat flour can increase amylase production (Figure 4). The result in this study showed that concentration of wheat flour $2 \%$ can increase amylase activity. Starch concentration $2 \%$ can increase amylase activity of Cronobacter sakazakii Jor52 (Samantha et al., 2013). It is different with Pseudomonas mendocina where starch concentration 5\% can increase amylase activity (Padhiar and Kommu, 2012). The increasing carbon source concentration can also increase amylase activity until a certain level. Too high of carbon source concentration can 
make the increasing of medium viscosity until it can disturb transferring $\mathrm{O}_{2}$ and limiting dissolved oxygen for bacterial growth (Rukhaiyar et al., 1995).

\section{Amylase stability}

Generally, some industries need thermostable amylase like amylase to optimize the result of medium growth condition of isolate bacterial (Figure 5). On the Figure 5, it looks that amylase stable for two hours at temperature 40$50^{\circ} \mathrm{C}$. In the other hands, at temperature 60 $90^{\circ} \mathrm{C}$ amylase loses its stability. Amylase of Bacillus sp strain SMIA-2 also stable for two hour at temperature $40-50^{\circ} \mathrm{C}$ (Cordeiro et al., 2002). It is different with amylase of Geobacillus thermoleovorans strain Rekadwadsis was stable for one hour at temperature $90^{\circ} \mathrm{C}$ (Rekadwad et al., 2015). Amylase of isolate bacterial PW13, PW11, and PS4 were stable for four hours at temperature $100^{\circ} \mathrm{C}$ (Sharma et al., 2015). Amylase stability was influenced by $\mathrm{pH}$ and temperature. The stable form of amylase is in polypeptide chain covalently bound and fold in the form of three dimentions with its specific pattern. The specific pattern of enzyme results in specific biological activity.

Thermostable amylase activity was high by using the agitation $125 \mathrm{rpm}$, wheat flour as the substrate at a concentration of $2 \%$ and amylase stability for 2 hours at $40-50^{\circ} \mathrm{C}$. Thermostable amylase produced SMG9 bacterial isolates can be used in various industries.

\section{Acknowledgements}

The authors thank the Directorate of high education (DIKTI) which has given funding this research.

\section{References}

Cordeiro CAM, Martins MLL, and Luciano AB. 2002. Production and properties of $\alpha$ amylase from thermophilic Bacillus sp.
Brazilian Journal of Microbiology 33:5761.

Dash BK, Rahman MM, and Sarker PK. 2015. Molecular identification of a newly isolated Bacillus subtilis BI19 and optimization of production conditions for enhanced production of extracellular amylase. BioMed Research International 2015: 19.http://dx.doi. org/10.1155/2015/859805

Deb P, Talukdar SA, Mohsina K, Sarker PK and Sayem SMA. 2013. Production and partial characterization of extracellular amylase enzyme from Bacillus amyloliquefaciens P001. Springer Plus 2(154): 1-12.

Fooladi J and Sajjadian A. 2012. Screening the thermophilic and hyperthermophilic bacterial population of three Iranian hotspring to detect the thermostable $\alpha$-amylase producing strain. Iranian Journal of Microbiology 2(1): 49-53.

Gao H and Wen-Ying. 2007. Optimization of polysaccharide and ergosterol production from Agaricus brasiliensis by fermentation process. Biochemical Engineering Journal 3: 202-210.

Ibrahim D, Zhu HL, Yosuf N, Isnaeni, and Hong LS. 2013. Bacillus licheniformis BT5.9 isolated from Changar hot spring, Malang, Indonesia, as a potential producer of thermostable $\alpha$-amylase. Tropical Life Sciences Research 24(1):71-84.

Jugran J, Rawat N, and GK. 2015. Amylase production by Geobacillus sp GJA1 isolated from a hot spring in Uttarakhand. ENVIS Bulletin Himalayan Ecology 23: 21-26.

Khalil A. 2011. Isolation and characterization of three thermophilic bacterial strain (lipase, cellulase and amylase producers) from hot spring in Saudi Arabia. African Journal of Biotechnology 10(44): 8834-8839. DOI: 10.5897/AJB10.1907.

Kumar SS, Sangeeta R, Soumya S, Ranjan RP, Bidyut B and Kumar DMP. 2014. Characterizing novel thermophilic amylase producing bacteria from Taptapani Hot Spring, Odishi, India. Jundishapur J Microbiol 7(12):1-12. DOI: 10.5812/jjm.11800.

Mageswari A, Subramanian P, Chandrasekaran S, 
Sivashanmugam K, Babu S, Gothandam KM. 2012. Optimization and immobilization of amylase obtained from halotolerant bacteria isolated from solar salterns. Journal of Genetic Engineering and Biotechnology 10:201-208.

Megahati, RRP, Mansyurdin, Agustien, A, Tjong DH. 2017. Optimization of bacteria amylase activity from Bacillus licheniformis Strain SEM11. Int.J.Curr.Microbiol.App.Sci. 6(11): 29382946.

Munoz J, Quintero M, and Gutierrez PA. 2011. Characterization of the amylase gene from Bacillus sp. BBM1.Universidad de Antioquia 18(3): 279-286.

Nabey HMA and Faraq AM. 2016. Production, optimization and characterization of extracellular amylase from halophilic Bacillus lichineformis AH214. African Journal of Biotechnology 15(17): 670683.DOI: 10.5897/AJB2015.15073.

Nelson N. 1944. A photometric adaptation of the Samogyi method for the determination of glucose. Journal of Biological Chemistry 153(2): 375-380.

Padhiar AR dan Kommu S. 2016. Isolation, characterization and optimization of bacteria producing amylase. International Journal of Advanced Research in Biological Science 3(7):1-7.

Rao, JLUM and Sathyanarayana T. 2003. Enhanced secretion and low temperature stabilization of a hyperthermostable and $\mathrm{ca}^{2+}$ dependent $\alpha$-amylase of Geobacillus thermoleovorans by surfactants. Lett. Appl. Microbiol 36(4): 191-196.

Rekadwad BN. 2015. Characterization of amylase from industrially important thermophilic microorganism: Geobacillus thermoleovorans strain Rekadwadsis. International Life Science Biotechnology and Pharma Research 4(1): 26-30.

Rukhaiyar R and Srivastava SK. 1995. Effect of various carbon substrates on a-amylase production from Bacillus species. World Journal of Microbiology and Biotechnology 10:76-82.

Samantha A, Mitra D, Roy SN, Sinha C, and Pal P. 2013. Characterization and optimization of amylase producing bacteria isolated from solid waste. Journal of Environmental Protection 4: 647652.http://dx.doi.org/10.4236/jep. 2013.46074.

Sharma P, Gupta S, Sourijajan A and Dev K. 2015. Characterization of extracelluler thermophilic amylase from Geobacillus sp isolated from Tattapani hot spring of Himachal Pradesh India. Current Biotechnology 4:1-8.

Sreekanth MS, Vijayendra SVV, Joshi GJ, and Shamala TR. 2013. Effect of carbon and nitrogen sources on simultaneous production of $\alpha$-amylase and green food packaging polymer by Bacillus sp. CFR 67 . Journal Food Sci Technol 50(2) :404-408.

Teodoro, CE dan Martins, MLL. 2010. Culture condition for production thermostabil alpha amylase by Bacillus sp. Braz. J. Microbial 31: 298-302.

Tiwari S, Sukla N, Mishra P, and Gaur R. 2014. Enhanced production and characterization of a solvent stable amylase from solvent tolerant Bacillus tequilensis RG-01: thermostable and surfactant resistant. The Scientific Wolrd Journal 2014:1-11.

Vengadaramana, Balakumar S, and Arasaratnam V. 2012. Production and optimization of $\alpha$ amylase by Bacillus licheniformis ATCC 6346 in lab Bench-Scale Fermenter. Journal of Microbiology and Biotechnology Research 2(1): 190-211.

Win T, Than WM, and Myint M. 2015. Study on the $\alpha$-amylase producing activity of isolated extreme bacteria. Proceedings of the IRES $11^{\text {th }}$ Bangkok, Thailand, $4^{\text {th }}$ October 2015.

\section{How to cite this article:}

Gustina Indriati and Ruth Rize Paas Megahati. 2018. Isolation of Thermophilic Bacteria and Optimizing the Medium Growth Conditions. Int.J.Curr.Microbiol.App.Sci. 7(01): 1457-1464. doi: https://doi.org/10.20546/ijcmas.2018.701.177 